\title{
Akciğer kanseri kemik metastazları
}

\author{
Lung cancer metastases to bone
}

\author{
Hüseyin Sina Coşkun ${ }^{1}$, Nevzat Dabak ${ }^{2}$ \\ ${ }^{1}$ T. C. Sağlık Bilimleri Üniversitesi, Samsun Eğitim ve Araştırma Hastanesi, Samsun \\ ${ }^{2}$ Samsun Ondokuz Mayıs Üniversitesi Tıp Fakültesi, Ortopedi ve Travmatoloji Anabilim Dalı, Samsun
}

\begin{abstract}
Akciğer kanseri günümüzde kansere bağlı mortalitenin en önemli nedenlerinden birisidir. Günümüzdeki tüm modern tanı ve teşhis yöntemlerine rağmen, akciğer kanserinin erken evrelerde tespiti çoğu hastada mümkün olmamaktadır. Akciğer kanserinin en önemli komplikasyonlarından birisi de kemik dokuya metastazdır. Akciğer kanseri kemiğe en sık metastaz yapan kanserler arasında 3. sırada bulunmakta olup, akciğer kanseri hastalarının yaklaşık \%40'ında hastalığın seyri boyunca kemik metastazı izlenir ve kemik metastazı görülen akciğer kanserlerinde sağkalım ciddi oranda azalır. Kemik metastazı olan hastalarda genellikle yük taşıyan bölgeler etkilendiği için, hastaların yaşam kalitesi ve mobilizasyonu belirgin oranda etkilenmektedir. Akciğerin kemik dokuya metastazlarına bağlı hastalıktaki tedavi yöntemleri, diğer odaklardan kaynaklanan metastatik kemik kanserindeki tedaviler ile benzerlikler taşır. Bu bilgiler ışığında tedavinin birincil amacı, metastazların neden olduğu ağrıyı azaltmak, kırıkları ve diğer komplikasyonları tedavi etmek veya bu komplikasyonları önleyerek hastanın yaşam kalitesini mümkün olduğunca artırmaktır. Metastatik kemik hastalığının genel tedavi yöntemleri; ağrıyı kontrol altına alan ilaçlar ve tekniklerle palyatif tedaviler, radyoterapi ile beraber medikal tedaviler, bisfosfonat ve radyoaktif izotoplar gibi kemiğe özel tedaviler ve cerrahi müdahaleleri içerir. Bu derleme makalede, akciğer kanseri ve türlerine genel bir bakıştan sonra, kemik metastazının patofizyolojisini ve tedavisini gözden geçireceğiz.
\end{abstract}

Anahtar sözcükler: akciğer kanseri; kemik metastazı; metastazlar
Lung cancer is one of the most important causes of cancerrelated mortality nowadays. Despite all modern diagnostic methods available today, early detection of the lung cancer is not always possible in most patients. One of the most important complications of lung cancer is metastasis to bone tissue. Lung cancer ranks third among the most common cancers that metastasize to bone, and approximately $40 \%$ of lung cancer patients have bone metastases during the course of the disease, and survival is significantly reduced in lung cancers with bone metastases. Quality of life and mobilization of patients are significantly decreased, as load bearing sites are usually affected in patients with bone metastases. The treatment methods in the lung tissue metastases are similar to the treatment of metastatic bone cancer caused by other foci. In the light of this information, the primary aim of treatment is to reduce the pain caused by metastases, to treat fractures and other complications, or to prevent these complications and improve the quality of life of the patient as much as possible. General treatment methods for metastatic bone disease include palliative treatments with pain-controlling drugs and therapies, medical treatments combined with radiotherapy, bonespecific treatments such as bisphosphonates and radioactive isotopes, and surgical interventions. In this review article, following the overview of lung cancer and its subtypes, we will review the pathophysiology and treatment of the bone metastasis.

Key words: lung carcinoma; bone metastasis; metastases

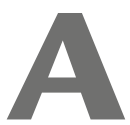

kciğer kanseri dünya çapında en sık görülen tümördür ve Avrupa'da kansere bağlı ölümlerin yaklaşık \%20'sinden sorumludur. ${ }^{[1]}$ Genel sağkalım oranları zayıftır. İleri evre akciğer kanseri hastalarının çoğunluğu tanıdan itibaren 18 ay içinde ölür. ${ }^{[2]}$ Akciğer kanserinin baskın şekli küçük hücreli dışındaki akciğer kanseridir (KHDAK) ve tüm akciğer tümörlerinin \%80-85'inden sorumludur. ${ }^{[3]}$

Akciğer kanseri sıklıkla kemiğe metastaz yapar. Farklı kanserlere sahip hastaların ölüm sonrası yapılan otopsi sonuçlarına göre, \%36'sında kemik lezyonu

- İletişim adresi: Op. Dr. Hüseyin Sina Coşkun, T. C. Sağlık Bilimleri Üniversitesi, Samsun Eğitim ve Araştırma Hastanesi, Samsun Tel: 0533 - 7667167 e-posta: sina.coskun@hotmail.com

- Geliş tarihi: 3 Eylül 2019 Kabul tarihi: 22 Ekim 2019 
saptanmış, \%22-60'ında ise kemik iliği mikro-metastazları gözlenmiştir. ${ }^{[4]}$ KHDAK'nin erken tanısı zordur ve KHDAK'li hastaların \%30-40', hastalıklarının seyri sırasında kemik metastazı geliştirir. ${ }^{[5]}$ Kemik metastazı olan akciğer kanseri hastalarının prognozu kötüdür. ${ }^{[4]}$ KHDAK hastaları nispeten kısa bir sağkalım süresine sahip olsalar bile, bu hastalarda sıklıkla iskeletle ilgili olaylar (skeletal related events -SRE) gelişir. Bu nedenle, kemik metastazlarının tedavisi oldukça titiz planlanmalıdır. Aslında, KHDAK hastalarında ağrı ve SRE'lere neden olana kadar kemik metastazları sıklıkla teşhis edilmez. Ancak, bir hasta bir kez SRE'ye maruz kaldığında, diğer olası komplikasyonları da deneyimlemesi muhtemeldir. Buna bağlı olarak, kemik lezyonları olan hastalarda yaşam kalitesi belirgin olarak düşer. ${ }^{[6]}$

Akciğer kanseri kemik metastazı, konvansiyonel röntgen görüntülemede osteolitik bir kemik lezyonu olarak gözlenir; kortikal yıkım gözlenmeyebilir ${ }^{[7]}$; genellikle omurgayı, kaburgaları, pelvisi ve uzun kemikleri etkiler. Erken aşamada, vertebral ven sistemi aracılı̆̆ıyla aksiyel bir kemikte, daha sonra hastalığın daha ileri evrelerinde appendiküler kemiklerde metastazın gözlendiğini, ilk olarak 1940 yılında Batson ortaya koymuştur. ${ }^{[8]}$ Bu tümörün bir başka özelliği, el ve ayak kemiklerine yayılma yeteneğidir. Diğer metastatik kemik lezyonlarının aksine, el ve ayak kemiklerine metastaz olduğunda akla ilk odak olarak akciğer kanseri gelmelidir. Bu muhtemelen, akciğer kanserinin metastaz yapan hücrelerinin, doğrudan arteriyel kan akımına karışabilmesi sonucu uzaklara ekilebilme yeteneğinden kaynaklanmaktadır. Intrakortikal metastatik tutulum olduğunda da akla ilk gelmesi gereken kanser türü akciğer kanseridir.

\section{AKCIĞER KANSERI TIPLERi}

İki ana akciğer kanseri türü vardır:

- Küçük hücreli dışındaki akciğer kanseri (KHDAK) ve

- Küçük hücreli akciğer kanseri (KHAK)

Akciğer kanserinde evreleme, kanserin bölgesel olup olmamasına veya akciğerlerden lenf bezlerine veya diğer organlara yayılmış olmasına dayanır. Akciğerler, tümör kitlesi ile karşılaştırıldığında göreceli olarak oldukça büyük olduğu için, bu bölgede bulunan tümör belli boyutlara ulaşıncaya kadar fark edilmez. Öksürük ve halsizlik gibi semptomlar ortaya çıktığında bile, insanlar bunun diğer patolojilerden kaynaklandığını düşünür. Bu nedenle, erken evre akciğer kanserini (Evre I ve II) tespit etmek zordur.

\section{Küçük Hücreli Dışındaki Akciğer Kanseri}

KHDAK, akciğer kanserlerinin yaklaşık yüzde 85'ini oluş̧urur ve şunları içerir:
- Adenokarsinom (ABD verilerine göre cinsiyet ayırmaksızın en sık görülen akciğer kanseri alt tipi)

- Skuamöz hücreli karsinom (tüm akciğer kanserlerinin \%25'i)

- Büyük hücreli karsinom (KHDAK'nin \%10'unu teşkil eder.)

KHDAK evrelemesi Tablo 1'de verilmiştir. ${ }^{[9]}$

\section{Küçük Hücreli Akciğer Kanseri}

KHAK, ABD'de akciğer kanserlerinin kalan yüzde 15 'inden sorumludur. KHDAK tümörlerinden daha hızlı büyümeye meyillidir. Genellikle KHAK, kemoterapiye KHDAK'den daha duyarlıdır (Tablo 2). ${ }^{[9]}$

American Joint Committee on Cancer (AJCC), küçük hücreli akciğer kanseri aşamalarının Roma rakamları ve harfleri (örn.; Evre IIA) kullanılarak tanımlandığı, daha ayrıntılı bir evreleme sistemi uygulamıştır. Bu sistem, KHDAK için kanserin büyümesini ve yayılmasını

Tablo 1. Küçük hücreli dışındaki akciğer kanserinin evrelemesi*

\begin{tabular}{cl}
\hline Evre I & $\begin{array}{l}\text { Kanser sadece akciğerlerde bulunur ve lenf } \\
\text { bezlerine yayılmamıştır. }\end{array}$ \\
Evre II & Kanser akciğerde ve yakındaki lenf bezlerindedir. \\
Evre III & $\begin{array}{l}\text { Kanser akciğerde ve mediastinal lenf } \\
\text { düğümlerinde bulunur ve ayrıca yerel olarak ileri } \\
\text { hastalık olarak tanımlanır. Evre III'ün iki alt tipi } \\
\text { vardır. }\end{array}$ \\
Evre IIIA & $\begin{array}{l}\text { Kanser sadece kanserin başladığı göğsün aynı } \\
\text { tarafındaki lenf düğümlerine yayılmıştır. }\end{array}$ \\
& $\begin{array}{l}\text { Kanser, göğsün diğer tarafındaki lenf } \\
\text { düğümlerine yayılmıştır. }\end{array}$ \\
& $\begin{array}{l}\text { Bu, akciğer kanserinin en ileri aşamasıdır } \\
\text { ve ayrıca ileri hastalık olarak da tanımlanır. } \\
\text { Kanserin her iki akciğere, plevral sıvıya veya } \\
\text { karaciğer veya diğer organlar gibi vücudun } \\
\text { başka bir kısmına yayıldığı zamandır. }\end{array}$
\end{tabular}

* https://www.lungcancer.org/find_information/publications/163-lung_ cancer_101/268-types_and_staging

Tablo 2. Küçük hücreli akciğer kanserinin evreleri*

Sınırlı evre Bu aşamada, göğsün bir tarafında, akciğerin sadece bir bölümünü ve yakındaki lenf düğümlerini içeren durumları kapsar.

Yaygın evre Bu aşamada kanser, göğsün diğer bölgelerine veya vücudun diğer bölgelerine yayılmıştır.

* https://www.lungcancer.org/find_information/publications/163-lung_ cancer_101/268-types_and_staging 
tarif etmekte kullanılan yöntemdir. Akciğer karsinomlarının en sık tespit edildiği zaman dilimi, genellikle hastalığın ileri formu olan, metastatik Evre IV aşamasıdır. Akciğer karsinomları, kan damarları aracılığının yanı sıra lenfatik olarak da metastaz yapar. Rezeke edilen akciğer karsinomlarında dikkatli bir histopatolojik değerlendirme yapıldığında, düşük evreli tümörlerde dahi vasküler invazyon sıklıkla görülür ve bu durum hastanın sağkalımı üzerine olumsuz etki etmekte olup, nüks oranının artmasına neden olmaktadır. Lenfatik yoldan metastaz, genellikle uzak metastaz oluşumunu takip ettiği için daha uzun zaman alırken, kan damarları yoluyla yayılma daha erken başlar. Akciğer karsinomlarının, beyin, kemik doku ve böbreküstü bezleri gibi metastaz için bazı öncelikli bölgeleri vardır. Diğer organlar, genellikle hastalığın geç evresinde tutulum gösterir. ${ }^{[10]}$

Akciğer kanserlerinin metastaz mekanizmasını tartışırken, hâlâ tam olarak cevaplanmayan birçok soru ortaya atılmaktadır.

1) Metastaz ne zaman ortaya çıkar?

2) Hücrelerin bırakıp göç etmeye başladığı belli başlı primer tümör boyutuna ihtiyaç var mı?

3) Tümör hücreleri, tümörden rastgele bir şekilde mi ayrılıp dolaşıma karışıyor, yoksa seçici klonlar olarak mı metastaz yeteneği kazanıyor?

4) Karsinoma hücreleri topluca mı yoksa tek hücre olarak mı hareket eder?

Bu sorular literatürde geniş bir şekilde tartışılmıştır, ancak özellikle akciğer kanserinde metastazı karşılaştırırken, bunların en azından bazılarına cevap vermek için birkaç iyi örnek vardır.

Küçük hücreli nöroendokrin karsinomun bazı benzersiz özellikleri vardır. İnvazyon mekanizmasına bakıldığında, bu karsinomun, üç ila beş hücreden oluşan tek hücreli veya küçük hücre kümeleri ile hareketi tercih ettiği açıtıtır. Kan ve lenfatik damarlarda, KHAK genellikle tek hücreli veya küçük hücreli kümeler olarak bulunur.

Buna karşılık skuamöz hücreli karsinom (SCC), büyük bir primer tümör oluşturabilir ve cerrahi olarak düzgün sınırlarda çıkarıldığında metastaz oluşturmayabilir. Hattâ bazı durumlarda, cerrahi sonrası bölgesel lenf düğümü metastazı bile saptanmayabilir. Metastaz yapan SCC, sıklıkla büyük hücre kompleksleri oluşturur; intravasküler dolaşımda büyük hücre kompleksleriyle birlikte görülür.

Adenokarsinomlarda, yukarıda bahsedilen mekanizmaların her ikisi ile de metastaz gözlenebilir. Solid veya müsinöz adenokarsinomların metastazı esnasında küçük hücre kümeleri bulunur; asiner veya papiller adenokarsinoma tiplerinde ise daha büyük kümeler halinde metastaz gözlenir.

Özetlemek gerekirse: akciğer kanserinin alt tiplerinin metastaz mekanizmalarının kendi içinde bile farklı olduğu görülmektedir. ${ }^{[10]}$

Akciğer karsinomlarının metastaz dağılımına baktığımızda; \%34,3 kemik, \%32 akciğer, \%28,4 beyin, $\% 16,7$ adrenal bez ve \%13,4 karaciğer gibi bazı tercih edilen bölgeler vardır. ${ }^{[11]}$

Akciğer kanseri hastalarının sağkalımı, son yıllarda sağlık alanındaki teknoloji ve gelişmeler sayesinde uzamıştır. Bununla birlikte, akciğer kanserinin kemik metastazı riski artmıştı. ${ }^{[12]}$ Kemik metastazı, akciğer kanserinde kötü prognoz göstergesidir. Bu nedenle, prognostik faktörleri tanımlamak hayati önem taşır.

Zhang ve ark.'ın çalışmasına göre adenokarsinom, kemik metastazı sıklığı ile ilişkili akciğer kanseri patolojik alt tipidir. ${ }^{[13]}$ Kemik metastazlarının en sık görüldügüu bölge omurga olup, bunu göguüs duvarı, pelvis ve kafatası takip eder. Bu bulgu, Wang ve ark.'ın çalışması ile de uyuşmaktadır. ${ }^{[14]}$ Akciğer adenokarsinomuna bağlı kemik metastazına en çok kostalar ve torakal vertebralarda rastlanır. ${ }^{[15]}$ Bunda muhtemelen, akciğerlere bölgesel yakınlığın bir rol oynadığı bildirilmiştir.

Ayrıca, tümör hücreleri kan dolaşımı yoluyla göç eder ve sarı kemik iliği bakımından zengin olan uzuvların kemiklerinden ziyade, kırmızı kemik iliği bakımından zengin olan gövde kemiklerinde çoğalır. Omurga kemikleri, tümör hücrelerinin kolonizasyonu ve göçü için elverişli bir durum sağlayan, bol miktarda kapiller damar içerir. Toraks bölgesi primer akciğer lezyonlarına yakın olduğu ve bol miktarda kılcal damar içerdiği için, tümör hücrelerinin torakal bölgedeki kemiklere yayılma olasılığı yüksektir. ${ }^{[16]}$

\section{BELIRTILER}

Ağrı, kemik metastazı olan akciğer kanserinin genellikle ilk belirtisidir. Ağrı başlangıçta bir kas spazmı veya gerilme gibi hissedilebilir, ancak yavaş yavaş kötüleşip şiddetli olabilir. Kemik metastazı ekstremiteleri içerdiğinde, hareketle birlikte ağrı daha da kötüleşir. Akciğer kanserinin omurgaya yayılmasından kaynaklanan ağrı, genellikle gece olur ve istirahat esnasında dahi kötüleşme eğilimindedir.

Kemik metastazları omurgayı tutarsa, tümör nedeniyle omurilik basısına, yürüme ve zayıflık ile ağrıya veya alt ekstremitede duyusal kayıplara neden olabilir. Omurilikteki şiddetli spinal bası, bazen kauda ekina sendromuna yol açabilir. Bacaklarda ağrı ve zayıflık, barsak veya mesane fonksiyonunun kaybı ile 
birlikte ortaya çıkan kauda ekina sendromu tıbbi bir 'acil durum'dur ve acil tedavi uygulanmadığı takdirde belirtiler kalıcı olabilir.

Bazen, akciğer kanserinin kemiğe yayıldığı ilk semptom patolojik kırık şeklinde olur. Kanser hücreleri normal kemik dokusunun yerini alır, zayıflatır ve böylece, önemli bir travma olmadan ve normal günlük aktiviteler sırasında kırıklar ortaya çıkabilir.

Kemiğin parçalanmasından dolayı kanda kalsiyum seviyesinin yükselmesi (hiperkalsemi) konfüzyona, bulantıya, kusmaya, susuzluğa ve kas zayıflığına neden olabilir. ${ }^{[17]}$

\section{TEŞHiS}

Akciğer kanserine bağlı kemik metastazlarını tespit etmek için kullanılan görüntüleme yöntemleri diğer kemik ve yumuşak doku tümörlerinin tespitinde kullanılan yöntemler ile benzerdir. Bunları özetleyecek olursak;

- Kemik taramaları: Kemik taramaları, kemik metastazlarını teşhis etmek için geçmişte olduğundan daha az kullanılır ve kanseri diğer kemik lezyonlarından ayırt etmek bazen zor olabilir. Gelişmiş teknoloji ile yerini pozitron emisyon tomografisi (PET), bilgisayarlı tomografi (BT) ve manyetik rezonans (MR) gibi ileri görüntüleme teknikleri almış olsa da, halen ilk basamak teşhis yöntemi konvansiyonel röntgen görüntülemeden oluşmaktadır.

- PET taramaları: PET taramaları, kemik metastazlarını saptama konusunda çok hassastır, çünkü kemikte aktif tümör büyümesi alanlarını görüntülemeye yardımcı olur.

- MR görüntüleme: Özellikle yumuşak dokudaki metastatik lezyonları tanımlamada önemli bir yer tutar. Sadece akciğer kanserine bağlı metastatik lezyonlarda değil, diğer metastaz ve yumuşak doku tümörlerinde de günümüzde altın standart olarak kullanılmaktadır. MR görüntüleme; T1 sekansında normal anatomik yapıların değerlendirilmesine izin verirken, T2 sekansında patolojik görüntüleri saptamamıza izin verir. Kontrast madde yardımı ile MR görüntüleme yapılacak ise hastanın böbrek fonksiyonlarının normal sınırlar içerisinde olması dikkat edilmesi gereken bir husustur.

- BT: Günümüzde metastatik kemik hastalı̆̆ının tespitinde yaygın olarak kullanılan başka bir yöntem de BT'dir. MR'den üstünlügüu, kemik dokuyu yumuşak dokudan daha iyi gösterebilmesidir. Kemik tutulumundan şüphelenildiği durumlarda
MR'den daha önce akla gelmesi gereken bir tetkik olup, kontrast madde kullanılacak ise, MR'de olduğu gibi, hastanın böbrek fonksiyonlarının normal olması gerekmektedir.

\section{AKCIĞER METASTATIK KEMIK HASTALIĞININ TEDAVisi}

Akciğer metastatik kemik hastalığının cerrahi tedavisinde amaç, genel tedavi planını en az etkileyecek ve ana tedavi planına mümkün olan en kısa arayı gerektirecek şekilde, ağıı miktarını ve lezyonun neden olduğu morbiditeyi sınırlandırmaktır. Metastatik kemik hastalığının hangi odaktan kaynaklandığı, günümüzde tedavi planını değiştiren etmenlerden birisi olarak kabul edilmemektedir. Ancak, lezyonun lokalizasyonu, blastik veya litik olması, radyoterapi veya kemoterapi duyarlıı̆ı tedavi planını etkiler. Dolayısıyla, akciğer kanseri metastazlarının tedavisinde uygulanan tedavi yöntemi ile diğer farklı odakların metastatik kemik hastalığı tedavisi benzerlik gösterir. Bu bilgiler ışığında; tedavinin birincil amacı, metastazların neden olduğu ağrıyı azaltmak, kırıkları ve diğer komplikasyonları tedavi etmek veya önlemektir.

Metastatik kemik hastalı̆̆ının genel tedavi yöntemleri; ağrıyı kontrol altına alan ilaçlar ve tekniklerle palyatif tedaviler, radyoterapi ile beraber medikal tedaviler, bisfosfonat ve radyoaktif izotoplar gibi kemiğe özel tedaviler ve cerrahi müdahaleleri içerir.

Palyatif yöntemler yalnızca, ağrıyı azaltmaya yönelik potansiyel girişimsel prosedürleri ve analjezik uygulanmasını içerir. Kemik spesifik bazı izotoplar (stronsiyum 89 , fosfor 32 , samaryum 153 , renyum 186 ), bazı durumlarda kemik lezyonlarına bağlı ağrıyı kontrol altına almaya yardımcı olur. İlaç tedavisi, her primer hastalık için spesifik olarak düzenlenmelidir.

Kemikte uygun yanıtın alındığı ve tüm hastalık seyri boyunca kullanılabilen bir ilaç tedavisi altındaki, asemptomatik ve zararsız kemik lezyonu olan hastalarda, tek başına gözlem kemik hastalığı için uygun olacaktır. Patolojik kırık riski çok yüksek olmayan semptomatik lezyonlarda, ağrı kontrolünde radyasyon terapisi hayli etkindir.

Stereotaktik radyo-cerrahi özellikle spinal metastazların yönetiminde kullanılan, göreceli olarak yeni bir radyoterapi tekniğidir. Ekstremite metastazlarının yönetiminde bu tekniğin kesin rolü aydınlatılmış olmasa da, radyasyona dirençli metastazları olan ve cerrahi için uygun olmayan hastalarda belirgin kullanım potansiyeli mevcuttur. Ekstremite metastazlarının yönetiminde bu tekniğin kesin rolünü belirlemek için gelecek çalışmalara ihtiyaç vardır. 

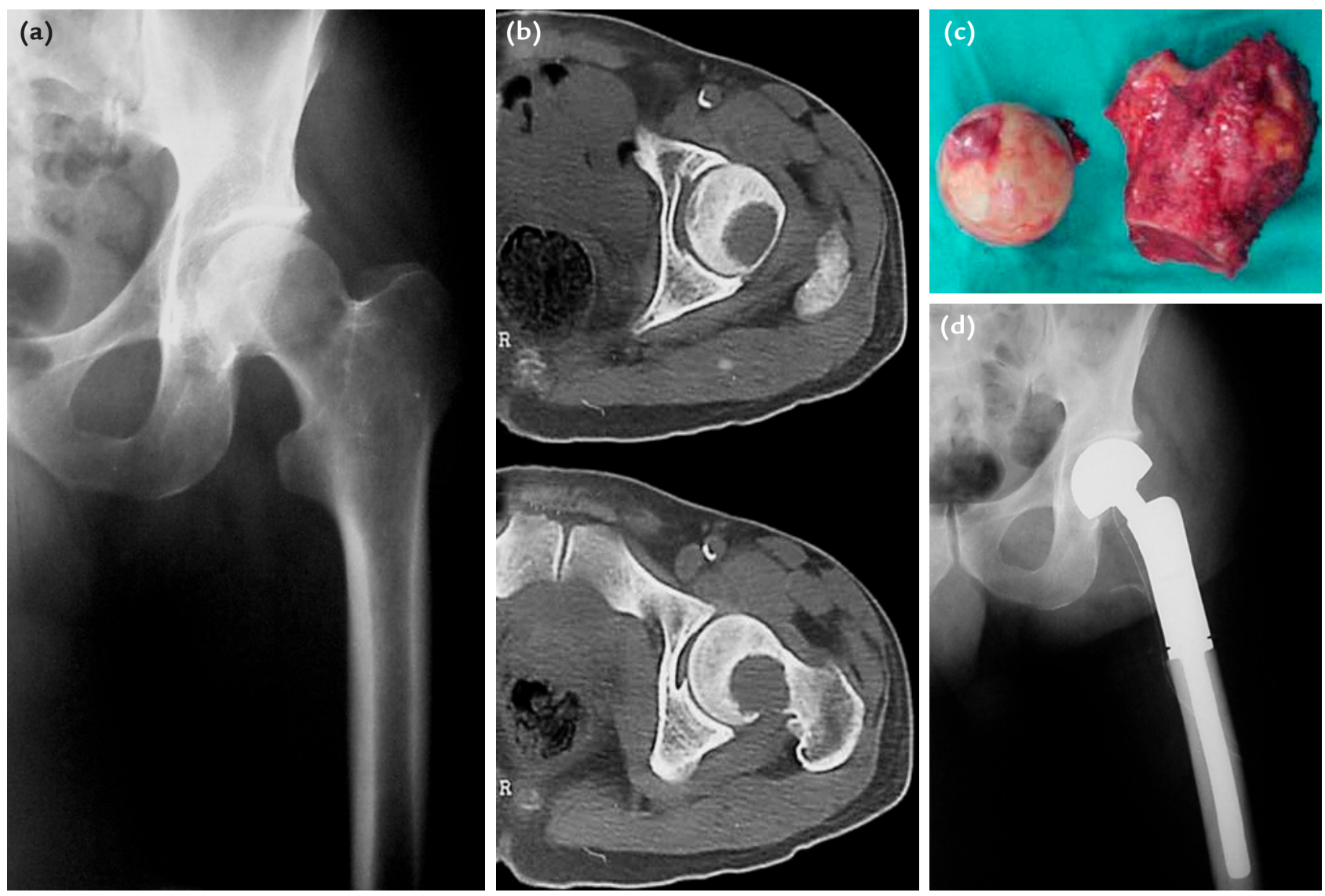

Şekil 1. a-d. Yetmiş iki yaşında, akciğer karsinomu nedeniyle takipli erkek hasta, yürürken sol kalçada ağrı tanımlamaktadır. Çekilen direkt grafisinde (a) femur baş-boyun bileşkesinde litik lezyon, BT tetkikinde ise (b) litik lezyonun sınırları net olarak gözükmektedir. Hastaya proksimal femur rezeksiyonu ve modüler parsiyel kalça protezi ile rekonstrüksiyon planlandı. Eksize edilen litik proksimal femur parçası patolojik incelemeye gönderildi. Patolojik inceleme sonucunda kalçadaki lezyonun akciğer metastazı olduğu görüldü $(c, d)$.

Epifiziyel ve periartiküler lezyonlarda, genellikle artroplastiye ihtiyaç duyulur. Lezyon subkondral değilse, plak tespiti ile beraber küretaj ve sementleme, yapısal stabiliteyi sağlamak için bir ihtimaldir; ancak elde edilen yapı, rekonstrüksiyon prosedüründe olduğu gibi, dayanıklı ve uygun olmaz. Bu durumlarda tedavi için verilecek karara, hastanın beklenen aktivite düzeyi ve yaşam süresi yardımcı olabilir. Eklem yüzeyini ilgilendiren lezyonlar, rezeksiyon ve rekonstrüksiyon gerektirir. Bu rezeksiyonlardan doğan defektleri doldurmak için, genellikle modüler endoprostetik rekonstrüksiyonlar gerekir (Şekil 1).

Patolojik kırıkların tedavisi zorlayıcı olabilir. Kırığa ek olarak sıklıkla, etkilenen kemiğin diğer bölgeleri stabilizasyon veya seçilmiş olgularda artroplasti gerektirir. Proksimal femur patolojik kırıklarında, küretaj ve intramedüller çivileme ile tespiti, protez uygulamasıyla kıyaslayan bir çalışmada, en düşük başarısızık oranı ve en dayanıklı sonuçlar protez uygulanan grupta grubunda bulunmuştur. ${ }^{[18]}$ Uzun kemiklerin distal veya proksimal kısımlarını etkileyen yaygın kemik yıkımının olduğu olgularda, rezeksiyon ve modüler tip protez ile rekonstrüksiyon gerekebilir (Şekil 2). Bu nedenle, bu zorlayıcı hastaların tedavisini üstlenmeden önce, her seçenek ve her seçeneğin başarı ihtimali dikkatlice değerlendirilmelidir.

Omurga ve pelvis gibi özellikli anatomik bölgeler ek zorluklar çıkarır. Bu bölgelerdeki cerrahi girişim ile ilgili temel problem, genellikle büyük çapta bir ameliyat olması nedeniyle, uzamış iyileşme zamanı ve buna bağlı uzamış ameliyat sonrası rehabilitasyondur. Pelvis ve asetabulumu hedef alan cerrahi müdahaleler, yüksek komplikasyon riski altındadır. Bunlar, hastanın beklenen prognozu, rehabilitasyonu ve iyileşme süreci de 
(a)

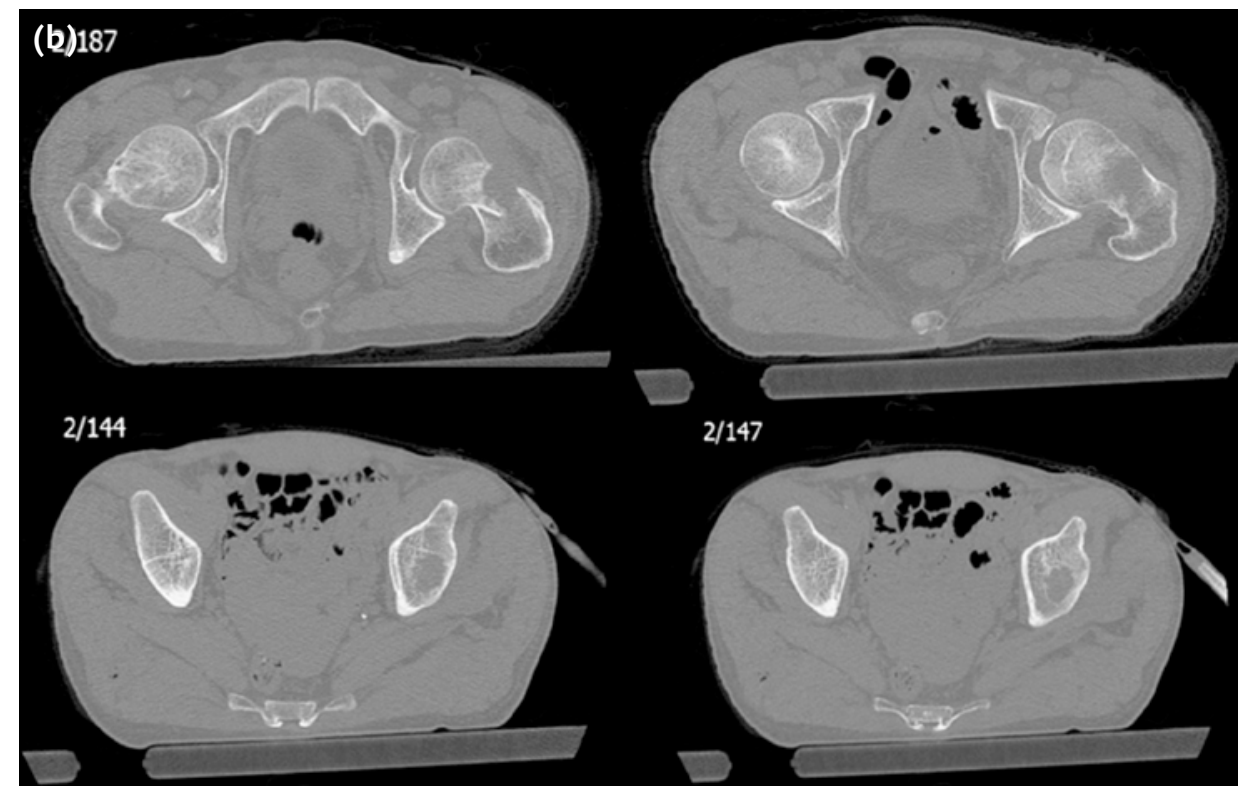

Şekil 2. a-c. Altmış yaşında erkek hastanın, metastatik küçük hücreli dışındaki akciğer karsinomu, sol femur boynunda litik lezyon ile birlikte patolojik kırk öyküsü vardır (a). Aynı hastaya ait BT görüntüleri (b). Hastaya uygulanan proksimal femur rezeksiyonu ile birlikte total kalça protezi operasyonunun operasyon sonrası röntgen görüntüsü (c).

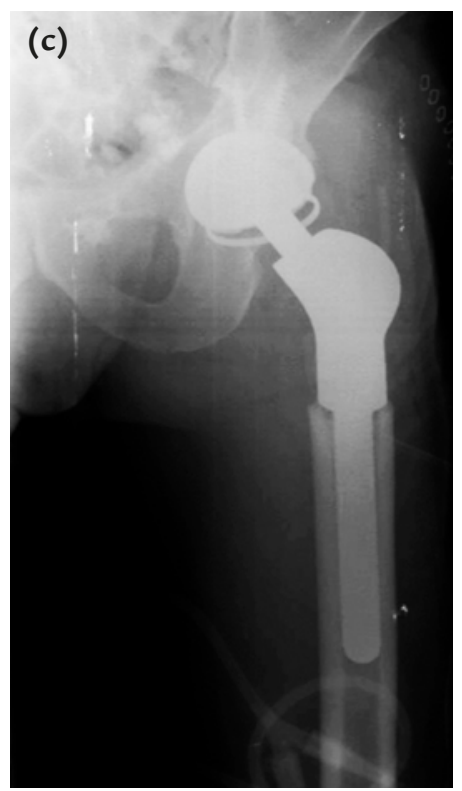

göz önünde bulundurularak, beklentileri geçmeyecek şekilde dikkatlice belirlenmelidir. Bu nedenle, pelvik ve asetabular prosedürler, diğer uzun kemik prosedürlerinden daha az sıklıkla yapılmaktadır. ${ }^{[19]}$

Metastatik kemik hastalığında, bazı durumlarda profilaktik tespit gerekebilir. Kırık riskini belirlemede en geçerli yöntem, birçok yeni teknik geliştirilmiş olmasına rağmen, kantitatif $\mathrm{BT}$ taramasıdır. Profilaktik tespit kararı için en sık kullanılan iki skorlama sistemi Mirels' ve Harrington skorlama sistemleridir.
Sonuç olarak; akciğer odaklı metastatik kemik hastalığında, sağkalım oranları düşüktür ve cerrahi tedavi yöntemlerinin yanı sıra, ileri evre hastalıkta palyatif metotlar da ön plana çıkar. Akciğer metastazlarının tedavi yöntemi, alt tiplerinde farklı metastaz mekanizmalarına sahip olsa da, diğer metastatik kemik hastalıklarınınki ile benzerlik taşır. Akciğer kanserinde kemiğe metastazın mekanizması tam olarak bilinmemektedir; ancak, günümüzde bu karmaşık yolağın ana hatları ve bazı baş aktörleri aydınlatılabilmiştir. 


\section{KAYNAKLAR}

1. De Angelis R, Sant M, Coleman MP, Francisci S, Baili $P$, Pierannunzio D, Trama A, Visser O, Brenner $\mathrm{H}$, Ardanaz E, Bielska-Lasota M, Engholm G, Nennecke A, Siesling S, Berrino F, Capocaccia R. Cancer survival in Europe 1999-2007 by country and age: results of EUROCARE--5-a populationbased study. Lancet Oncol 2014;15(1):23-34. Crossref

2. Langer CJ, Besse B, Gualberto A, Brambilla E, Soria JC. The evolving role of histology in the management of advanced non-small-cell lung cancer. J Clin Oncol 2010;28(36):531120. Crossref

3. D'Addario G, Fruh M, Reck M, Baumann P, Klepetko W, Felip E; On behalf of the ESMO Guidelines Working Group. Metastatic non-small-cell lung cancer: ESMO Clinical Practice Guidelines for diagnosis, treatment and follow-up. Ann Oncol 2010;21(Suppl 5):v116-9. Crossref

4. Coleman RE. Clinical features of metastatic bone disease and risk of skeletal morbidity. Clin Cancer Res 2006;12(20 Pt 2):6243s-9s. Crossref

5. Tsuya A, Kurata T, Tamura K, Fukuoka M. Skeletal metastases in non-small cell lung cancer: a retrospective study. Lung Cancer 2007;57(2):229-32. Crossref

6. Iordanidou L, Trivizaki E, Saranti S, Georgakopoulos A, Bolanos N, Baltagiannis N, Koutsiouba P. Is there a role of whole body bone scan in early stages of non small cell lung cancer patients. J BUON 2006;11(4):491-7. Erişim: https:// www.jbuon.com/archive/11-4-491.pdf

7. Coleman RE. Metastatic bone disease: clinical features, pathophysiology and treatment strategies. Cancer Treat Rev 2001;27(3):165-76. Crossref

8. Batson OV. The Function of the Vertebral Veins and Their Role in the Spread of Metastases. Ann Surg 1940;112(1):138-49. Crossref

9. lungcancer.org, "A Program of Cancer Care". Lung Cancer 101. Erişim: https://www.lungcancer.org/find_information/ publications/163-lung_cancer_101/265-what_is_lung_cancer
10. Popper $\mathrm{HH}$. Progression and metastasis of lung cancer. Cancer Metastasis Rev 2016;35(1):75-91. Crossref

11. Tamura T, Kurishima K, Nakazawa K, Kagohashi K, Ishikawa $\mathrm{H}$, Satoh H, Hizawa N. Specific organ metastases and survival in metastatic non-small-cell lung cancer. Mol Clin Oncol 2015;3(1):217-21. Crossref

12. Cook RJ, Major P. Multistate analysis of skeletal events in patients with bone metastases. Clin Cancer Res 2006;12(20 Pt 2):6264s-9s. Crossref

13. Zhang L, Gong Z. Clinical Characteristics and Prognostic Factors in Bone Metastases from Lung Cancer. Med Sci Monit 2017;23:4087-94. Crossref

14. Wang Z-Y, Ning L-L, Li H-T, Yang Y-M, Wu C-G, Zhao H, Yang $Y$. Clinical observation of percutaneous osteoplasty in the treatment of 92 lung cancer patients with extraspinal bone metastases. Tumor 2014;34(5):443-9. Crossref

15. Wang CY, Zhang XY. (99m) Tc-MDP wholebody bone imaging in evaluation of the characteristics of bone metastasis of primary lung cancer. Zhonghua Zhong Liu Za Zhi 2010;32(5):382-6.

16. Bae HM, Lee SH, Kim TM, Kim DW, Yang SC, Wu HG, Kim WW, Heo DS. Prognostic factors for non-small cell lung cancer with bone metastasis at the time of diagnosis. Lung Cancer 2012;77(3):572-7. Crossref

17. Cooley ME. Symptoms in adults with lung cancer: a systematic research review. J Pain Symptom Manage 2000;19(2):13753. Crossref

18. Steensma M, Boland PJ, Morris CD, Athanasian E, Healey $\mathrm{JH}$. Endoprosthetic treatment is more durable for pathologic proximal femur fractures. Clinical Orthop Relat Res 2012;470(3):920-6. Crossref

19. Cannada LK, editor. Orthopaedic Knowledge Update 11. USA: American Academy of Orthopaedic Surgeons; 2014. 